TATA LOKA

Volume 22 Nomor 1, Februari 2020, 27-40

\title{
Peningkatan dan Penguatan Partisipasi Masyarakat dalam Konteks Smart City
}

\author{
Smart City: A Platform for Enhancing and Strengthening Community \\ Participation in Bandung, Indonesia.
}

\section{Yunita Arafah $^{1,2}$ dan Haryo Winarso ${ }^{1}$}

Diterima: 19 Januari 2019

Diterima: 29 Mei 2019

\begin{abstract}
Konsep smart city telah digunakan secara meluas di berbagai bidang, namun secara umum masih didominasi oleh bidang-bidang yang berhubungan dengan teknologi informasi dan komunikasi, serta komputer dan keteknikan. Padahal tidak hanya itu, pembahasan smart city dalam bidang sosial juga merupakan sebuah prioritas. Hal ini juga dapat dilihat dari kecenderungan evolusi perkembangan konsep smart city dari tahun ke tahun yang terus mengarah dan fokus kepada aspek manusia dan masyarakat di dalamnya, salah satunya yaitu bagaimana manusia sebagai pengguna smart city dapat ikut berpartisipasi dalam menyelesaikan permasalahan kota dan ikut berpartisipasi dalam pembangunan. Tulisan ini bertujuan untuk melihat sejauh mana tingkat partisipasi masyarakat dalam konsep smart city yang telah berjalan, khususnya pada kasus kota-kota di Indonesia, selanjutnya melihat faktorfaktor apa saja yang menjadi prioritas dalam usaha peningkatan dan penguatan partisipasi masyarakat dalam konteks smart city. Studi ini akan fokus pada teori smart city, partisipasi, smart community, smart people, dan smart governance sebagai salah satu karakter pembentuk smart city. Analisa dan pembahasan dilakukan berdasarkan studi literatur, dan menggunakan metodologi systematic literature review melalui rangkuman hasil penelitianpenelitian sebelumnya dengan teknik deskriptif kualitatif.
\end{abstract}

Kata kunci: smart city, smart community, partisipasi, smart people, smart governance.

\begin{abstract}
The smart city concept has been used extensively in various fields. However, it mostly dominated by fields related to Information and Communication Technology (ICT), as well as computers and engineering only. In fact, the use of this concept in social fields is also critical. It can be seen from the evolutionary trend of the smart city concept development from year to year which continues to lead and focus on the human and community aspects, one of which how humans as the users of this concept can participate in solving city problems and participate in development of the city. This paper aims to see how far the level of community participation in smart city concept has been running, especially in the case of cities in Indonesia. Then it also intends to look at which factors are the priorities in an attempt to increase and strengthen the community participation. This study will focus on the theory of smart city, participation, smart community, smart people, and smart governance as the characters forming of the smart city. Systematic literature review by analyzing summaries of previous studies results will be used to collect data. The results and discussion will be presented in qualitative descriptive techniques.
\end{abstract}

Keywords: smart city, smart community, participation, smart people, smart governance

\footnotetext{
${ }^{1}$ Perencanaan Wilayah dan Kota, Sekolah Arsitektur Perencanaan dan Pengembangan Kebijakan, Institut Teknologi Bandung

2 Jurusan Arsitektur dan Perencanaan, Universitas Syiah Kuala
} 


\section{PENDAHULUAN}

Ide orisinal smart city awalnya bertujuan untuk meningkatkan kualitas kota menjadi 'smart' melalui peningkatan infrastruktur teknologi khususnya ICT (Information Communication and Technology) dalam wilayahnya, dengan cara mengembangkan aplikasi-aplikasi perangkat lunak serta bekerjasama dengan pihak swasta. Namun seiring berjalannya waktu, perkembangan konsep smart city juga mengalami peningkatan yang cukup pesat, baik dalam hal publikasi dan aplikasi, khususnya sejak European Union pada tahun 2010 memunculkan proyek smart city yang bertujuan untuk mengembangkan solusi yang cerdas dalam menghadapi tantangan urbanisasi, globalisasi, dan perubahan iklim (Jucevičius dkk., 2014; Cocchia, 2014). Beberapa alasan lain yang juga mendukung perkembangan smart city, antara lain yaitu: meluasnya penggunaan perangkat teknologi seperti telepon genggam (mobile devices) dan internet di kalangan masyarakat, dimensi perkotaan yang terus bertambah tinggi, dan adanya kebutuhan untuk menjaga lingkungan dari polusi dan konsumsi energi (Oberti \& Pavesi, 2013).

Salah satu pembahasan paling menonjol dalam konsep smart city adalah diskusi yang lebih menitikberatkan kepada pengembangan teknologi komputer dan teknologi informasi komunikasi (TIK). Padahal pemaknaannya tidak hanya sebatas itu, namun juga telah meluas ke berbagai bidang seperti dalam bidang sosial, lingkungan, bisnis dan manajemen, energi, dan sebagainya. Dua kelompok konsep utama yang terdapat dalam smart city yaitu: (1) konsep smart city yang berorientasi pada teknologi dan TIK atau infrastruktur keras (hard infrastructure) atau juga disebut dengan perangkat keras (hardware) (IEEE, 2014; Townsend, 2013; European Commission, 2012; Su dkk., 2011; Hall, 2000); dan (2) konsep smart city yang fokus kepada masyarakat, inklusi, dan partisipasi atau disebut sebagai infrastruktur lunak (soft infrastructure), dan terkadang juga disebut sebagai perangkat lunak (software) (Angelidou, 2014; Dameri \& Rosenthal-Sabroux, 2014; Rudolf dkk., 2007; Bosch, 2017).

Dari kedua kelompok ini, konsep smart city yang fokus kepada hard infrastructure masih mendominasi. Hal ini dapat dilihat dari dua ribu lebih publikasi tentang smart city berdasarkan data Scopus, lebih dari 50 persen pembahasannya berada di bidang ilmu komputer dan teknologi, sedangkan sisanya membahas konsep smart city dari beragam bidang ilmu lain, seperti sosial, lingkungan, dan lain sebagainya (Colding \& Barthel, 2017).

Dominasi terhadap TIK ini menimbulkan berbagai kritik, antara lain oleh (Krivý, 2016): 1) Disebabkan karena karakter kota yang tidak dapat diprediksi, maka konsep smart city yang selama ini memberi kesan formal dianggap tidak sesuai dengan karakter kota yang lebih mengarah kepada sifat informal; 2) konsep smart city yang ada selama ini lebih mengarahkan kota pada orientasi bisnis dan profit, hal ini disebabkan karena pengaruh kekuatan dan keberadaan perusahaan-perusahaan TIK yang bekerjasama mengelola kota; 3) Akibat dari kedua hal tersebut di atas, maka konsep smart city berpotensi menciptakan kondisi kota yang tidak setara dan akhirnya menimbulkan kesenjangan sosial di masyarakat. Kritik lain juga disampaikan oleh Colding \& Barthel, (2017) yang menyatakan bahwa dominasi terhadap TIK dalam konsep smart city dapat menciptakan perubahan hubungan antara manusia dan alam, sehingga dibutuhkan adanya analisis dan pendekatan baru untuk membentuk hubungan psikologis yang lebih kuat dengan alam, dan prilaku yang lebih berpihak kepada lingkungan.

Konsep smart city dapat dibagi menjadi tiga kelompok utama (Papa dkk., 2015) yaitu: berawal dari fokus hanya kepada hardware atau disebut juga smart city as digital city, selanjutnya fokus kepada software yang dikenal dengan istilah smart city as social inclusive city, dan pada periode terakhir fokus terhadap keduanya, yaitu 'hardware' dan 'software' yang membentuk smart city sebagai kota yang memiliki kualitas hidup yang tinggi. Dari tahapan perkembangan ini, kebutuhan partisipasi masyarakat terlihat pada 
tahap yang terakhir, yaitu Smart city as city with high quality of life. Pada tahap ini konsep telah fokus pada hard infrastructure dan soft infrastructure. Teknologi saja dianggap tidak akan cukup (karena dapat dicontoh dan dimodifikasi), infrastruktur lunak menjadi lebih penting karena berorientasi kepada manusia. Pencapaian yang diharapkan dapat terwujud pada tahap ini yaitu terciptanya kualitas hidup yang lebih baik melalui pemanfaatan TIK dalam meningkatkan kesadaran, kecerdasan, kesejahteraan, dan partisipasi warga.

Salah satu penelitian sebelumnya yang telah membahas dan mengaitkan pentingnya antara konsep smart city dan partisipasi yaitu adanya tiga kelompok perkembangan konsep smart city yang menuju partisipatif, yaitu: smart city 1.0, smart city 2.0, dan smart city 3.0. (Bosch, 2017). Kelompok smart city 1.0 menggunakan pendekatan teknologi maju secara maksimal dan teknologi dianggap berperan penting bagi kelangsungan hidup, keberlanjutan, dan pengendalian suatu kota. Kelompok smart city 2.0 mulai menggunakan teknologi dengan sangat hati-hati dan teknologi hanya dimanfaatkan untuk menyelesaikan permasalahan tertentu saja. Selain itu, pada kelompok ini peran warga kota sudah mulai dilibatkan dalam menyeleksi teknologi yang digunakan dan dalam pengambilan keputusan, namun partisipasi warga dianggap hanya sebagai formalitas dan jumlah partisipan yang terlibat juga masih sangat kecil. Kelompok smart city 3.0 terbentuk ketika partisipasi dan keterlibatan warga kota sudah mulai meningkat serta terciptanya kegiatan dan tindakan yang bersifat kolaboratif dengan tujuan yang lebih luas, yaitu untuk meningkatkan inklusi sosial, meningkatkan demokrasi, dan megembangkan modal sosial di masyarakat (Bosch, 2017).

Perjalanan konsep smart city dari waktu ke waktu menggambarkan bahwa kebutuhan akan keterlibatan dan partisipasi masyarakat menjadi sebuah tujuan mewujudkan smart city yang lebih baik. Smart city ke depan akan menjadi suatu konsep yang memberikan peluang sebesar-besarnya bagi masyarakat untuk sadar akan persoalan yang mereka hadapi dan potensi yang mereka miliki, sehingga masyarakat dapat masuk dalam proses penentuan kebijakan, penyelesaian masalah kota, solusi kota, dan meningkatkan pelayanan kota.

Dari penjelasan di atas, dapat dilihat bahwa perkembangan smart city saat ini cenderung mengarah kepada pendekatan yang lebih fokus kepada perangkat lunak secara umum, dan pentingnya partisipasi masyarakat secara khusus. Selain bertujuan untuk meningkatkan inklusi sosial, meningkatkan demokrasi, dan megembangkan modal sosial di masyarakat (Bosch, 2017), partisipasi juga dibutuhkan sebagai usaha untuk mewujudkan smart city yang sesuai dengan karakter dan kebutuhan warga, melayani permasalahan perkotaan melalui partisipasi atau aduan warga, serta memenuhi hak masyarakat dalam proses pembangunan kota.

Dominasi TIK dalam konsep smart city seharusnya tidak membuat partisipasi masyarakat menjadi kurang diperhatikan dan bahkan perlahan-lahan hilang, namun justru sebaliknya. Partisipasi masyarakat seharusnya menjadi salah satu tujuan utama dalam menjalankan konsep smart city. Namun pertanyaannya adalah, apakah kondisi perkembangan TIK yang begitu pesat dapat menjadi pendorong bagi masyarakat untuk lebih partisipatif? dan apakah dibutuhkan unsur-unsur pendukung lainnya di samping teknologi untuk meningkatkan partisipasi masyarakat untuk pembangunan kota yang lebih baik? Berdasarkan pertanyaan-pertanyaan tersebut, maka tulisan ini bertujuan untuk melihat faktor apa saja yang harus ada dan bagaimana faktor-faktor tersebut dapat mewujudkan partisipasi masyarakat yang lebih baik berdasarkan teori smart city dan partisipasi, serta beberapa konsep lainnya yang ada di dalam konsep smart city. 


\section{METODE}

Analisa dan pembahasan dilakukan berdasarkan studi literatur, dan menggunakan metodologi systematic literature review. Metodologi ini dilakukan dengan merangkum hasil-hasil penelitian sebelumnya yang menyajikan fakta yang lebih komprehensif dan berimbang. Sintesis hasil dilakukan menggunakan teknik naratif atau teknik kualitatif. Pendekatan kualitatif dalam metodologi systematic literature review digunakan untuk mensintesis hasil-hasil penelitian sebelumnya yang bersifat deskriptif kualitatif. Metode merangkum hasil penelitian kualitatif ini disebut dengan meta-sintesis, yang merupakan teknik dalam melakukan integrasi data untuk mendapatkan teori maupun konsep baru dalam tingkatan pemahaman yang lebih mendalam dan menyeluruh (Perry \& Hammond, 2002).

Pengambilan data dalam metodologi systematic literature review dilakukan melalui searching internet jurnal-jurnal dan hasil penelitian terbaru yang telah dipublikasi.

Langkah-langkahnya adalah sebagai berikut: (Francis \& Baldesari, 2006):

1. Melakukan formulasi terhadap pertanyaan penelitian

2. Melakukan pencarian literature systematic review

3. Melakukan seleksi artikel penelitian yang cocok

4. Melakukan analisis dan sintesis temuan-temuan

5. Memberlakukan kendali mutu

6. Menyusun laporan akhir

Dalam pendekatan meta-agregasi (meta-aggregation), topik penelitian dielaborasi menjadi tema-tema tertentu untuk menghasilkan kerangka analisis (conceptual framework). Kemudian, dalam tema-tema tertentu tersebut dilakukan pencarian artikel hasil penelitian yang relevan dan dibandingkan dan dirangkum antar yang satu dengan yang lainnya. Pada pendekatan meta-agregasi (meta-aggregation), ini, hasil sintesis merupakan "agregat" dari berbagai hasil penelitian sesuai dengan tema yang relevan. Proses sintesis pada pendekatan ini akan melalui beberapa langkah yaitu: (1) tema-tema dan konsep dari studi yang relevan diekstraksi, (2) hasil ekstraksi ini ditata menjadi temuan penting (utama/primer); (3) temuan-temuan dikelompokkan ke dalam kategori; (4) kategori-kategori kemudian disintesis menjadi tema (disesuaikan dengan kerangka konseptual yang disusun).

\section{HASIL DAN PEMBAHASAN}

Ide smart city sebenarnya bukanlah hal baru, namun pembahasan dan perdebatannya masih terus hangat didiskusikan oleh para peneliti hingga saat ini. Definisi smart city juga berkembang luas dalam berbagai bidang, sehingga belum ada persetujuan dan kesepahaman bersama dalam pemaknaannya yang digunakan secara konsisten (Angelidou, 2015); (Chourabi dkk., 2012); (Caragliu, dkk., 2011); (Hollands, 2008); (MarsalLlacuna, dkk., 2015); (Wall \& Stavropoulos, 2016); (Meijer \& Bolívar, 2016).

Pendekatan dalam konsep smart city dapat dibagi menjadi dua kelompok utama, yaitu: (1) konsep smart city yang berorientasi dan fokus pada teknologi dan informasi komunikasi atau infrastruktur keras (hard infrastructure), yang salah satu tujuan utamanya yaitu untuk memperbaiki kualitas hidup dan penurunan kualitas lingkungan (IEEE, 2014; Townsend, 2013; European Commission, 2012; Su dkk., 2011; Hall, 2000); dan bertolak belakang dengan hal tersebut, sekelompok peneliti lainnya juga memperdebatkan tentang pentingnya (2) konsep smart city yang berorientasi dan fokus kepada masyarakat, inklusi, dan partisipasi atau disebut juga sebagai infrastruktur lunak (soft infrastructure) dengan tujuan untuk dapat meningkatkan kualitas hidup dan lingkungan, mengembangkan 
kecerdasan, meningkatkan kesejahteraan, keefektifan, dan daya saing (Angelidou, 2014; Dameri \& Rosenthal-Sabroux, 2014; Rudolf dkk., 2007).

Dari kedua pendekatan tersebut, selama ini pendekatan yang berorientasi kepada infrastruktur keras dan TIK dinilai lebih mendominasi dibandingkan dengan pendekatan yang berorientasi kepada soft infrastructure. Hal ini salah satunya dapat dilihat dari jumlah publikasi tentang smart city yang mengalami peningkatan signifikan di berbagai bidang yang terkait. Dari 2000 lebih publikasi (Colding \& Barthel, 2017), sebagian besar penelitian yang telah dilakukan berasal dari bidang ilmu komputer dan teknologi (computer science and engineering), lalu diikuti dengan penelitian dalam bidang ilmu sosial, matematika, dan beberapa bidang lainnya. Oleh sebab itu diskusi di bidang ilmu sosial dalam konteks smart city harus didorong dan ditingkatkan jumlahnya serta diperluas bidang bahasannya. Hal ini disebabkan karena pemahaman konsep smart city pada dasarnya tidak hanya terbatas pada pemanfaatan TIK, big data, Internet of Things dan beragam teknologi modern saja, namun saat ini telah meluas ke berbagai bidang, salah satu yang paling utama adalah pendalaman dalam bidang ilmu sosial.

Dalam rangka mewujudkan dan meningkatkan partisipasi masyarakat, maka dapat disimpulkan bahwa pendekatan ke arah soft infrastructure harus lebih didahulukan sebelum menuju kepada pendekatan hard infrastructure. Suatu kota dapat menjadi "smart" ketika investasi yang dikembang di kota tersebut tidak hanya difokuskan pada transportasi dan TIK yang modern, namun juga pada aspek modal manusia (human capita) dan modal sosial (social capita), agar dapat menciptakan pertumbuhan ekonomi berkelanjutan serta kualitas hidup yang tinggi, dengan manajemen yang baik pada sumber daya alam melalui pemerintahan yang partisipatif (Caragliu dkk., 2011).

\section{Smart City Menuju Partisipatif}

Berdasarkan model konseptual yang dikemukakan oleh Nam \& Padro (2011), konsep smart city terdiri dari tiga dimensi utama yaitu teknologi, manusia, dan institusi. Smart city menuju partisipatif diwujudkan melalui salah satu dimensinya yaitu institusi. Institusi merupakan tata kelola pemerintahan untuk meningkatkan peran kelembagaan, partisipasi, dan keterlibatan masyarakat. Dimensi ini terdiri atas elemen-elemen pendukungnya seperti pemerintah, kebijakan-kebijakan, dan regulasi. Namun, dalam mewujudkan smart city yang partisipatif, mendorong faktor institusi saja tidaklah cukup, perpaduan antara ketiga dimensi tersebut harus dimanfaatkan agar tercipta partisipasi masyarakat seperti yang diharapkan. Faktor institusi saja tidak akan dapat berjalan sendiri bila tidak didukung dan diperkuat oleh faktor-faktor lainnya, yaitu manusia dan teknologi. Secara khusus, konsep yang menggambarkan penguatan faktor institusi adalah smart community (Nam \& Pardo, 2011).

Pemerintahan di negara-negara maju telah menuju model pemerintahan yang demokratis dan partisipatif. Masyarakat diberikan keleluasaan dan ruang untuk masuk dalam proses dan penentuan kebijakan pemerintahan. Pemerintahan partisipatif memberikan peluang bagi masyarakat untuk sadar akan persoalan yang mereka hadapi dan potensi yang mereka miliki. Sehingga nantinya pembangunan diharapkan dapat lebih menyentuh masyarakat, pembangunan menjadi lebih efektif dan efisien dalam pemanfaatan sumber dayanya, masyarakat lebih bertanggung jawab atas pada pembangunan dan pemanfaatan hasil pembangunan, masyarakat dapat belajar melalui proses pembangunan, menciptakan solidaritas di masyarakat, serta membentuk karakteristik masyarakat yang mandiri dan mampu memutuskan hal-hal yang berpengaruh terhadap masa depannya (Parwoto, 1997). 
Kata partisipasi maknanya berasal dari kata pars dan capere, pars berarti bagian, sedangkan capere berarti mengambil. Partisipasi disadur dari bahasa inggris yaitu participation, yang artinya adalah pengambilan bagian atau pengikutsertaan (Salakory, 1997). Ide-ide dalam partisipatif lebih memperhatikan pengikutsertaan hak-hak yang lebih luas seperti hubungan antar negara dan masyarakat serta memberikan kesempatan untuk masyarakat dalam pengambilan keputusan (Peters, 1996). Sebuah pembangunan akan lebih berhasil jika masyarakatnya memiliki dan menciptakan komitmen untuk ikut berperan serta sebagai pelaku pembangunan dan didukung oleh anggota masyarakat yang dapat dijadikan sebagai panutan, pengarah, pembimbing dan motivator (Siagian, 2000). Oleh sebab itu, partisipasi warga sangat dibutuhkan karena sebenarnya mereka adalah pelaksana berbagai kegiatan pembangunan yang ada. Dalam rangka menciptakan partisipasi masyarakat, maka penting untuk melaksanakan beberapa hal seperti: hal tersebut dapat menguntungkan masyarakat; dapat dipahami maknanya oleh masyarakat; dilaksanakan sesuai konteks dan maksudnya, dilaksanakan secara jujur, terbuka, dan dapat dipertanggungjawabkan, serta yang pasti harus melibatkan masyarakat dalam pelaksanaanya.

Partisipasi masyarakat dapat berada di atas bentuk-bentuk kelembagaan demokrasi yang konvensional pada tataran tujuan praktis, seperti memperbaiki respon dan efektifitas pemerintahan. Selain itu, melalui partisipasi masyarakat dapat menciptakan kondisi dan situasi yang lebih baik, lebih adil, lebih terlibat, penuh pertimbangan dan bertanggung jawab. Terdapat tiga dimensi partisipasi langsung yang menjadi faktor penting dalam model pemerintahan partisipatif (Fung, 2006), yaitu: 1) pihak yang berpartisipasi, yaitu dapat dilakukan secara terbuka bagi warga masyarakat yang ingin terlibat, sedangkan proses lainnya juga dapat melibatkan pihak-pihak berkepentingan yang mewakili; 2) partisipasi yang menciptakan suatu hasil atau keputusan, dari pada hanya membangun komunikasi, umumnya partisipan hanya sebagai pendengar dan tidak ikut andil dalam memberikan keputusan tertentu; 3) adanya hubungan antara diskusi, aktivitas publik, dan kebijakan (policy). Fung (2006) juga menyatakan bahwa partisipasi harus menyediakan tiga nilai demokrasi yang sangat penting, yaitu: legitimasi (legitimacy), keadilan (justice), dan efektifitas tindakan publik (effectiveness of public action).

Tipologi partisipasi dikembangkan untuk memahami perbedaan antar interpretasi, pendekatan, dan metode yang ada, serta pemahaman terhadap perbedaan dalam konteks yang paling diprioritaskan. Pembagian tipologi ini dapat menjadi sebuah acuan dalam memilih metode yang sesuai dalam tipe partisipasi yang dibutuhkan, dan merupakan kategorisasi dari tipe partisipasi yang ada (Reed, 2008). Terdapat empat jenis kategorisasi tipologi partisipasi (Reed, 2008), yaitu: 1) tipologi berdasarkan perbedaan tingkat partisipasi dalam sebuah rangkaian kesatuan. Sebagai contoh, tipologi tangga partisipasi oleh Arnstein (1969) dan tipologi roda partisipasi oleh Davidson (1998); 2) tipologi berdasarkan sifat dasar partisipasi yang sesuai dengan arah arus komunikasi. Contohnya yaitu seperti yang ditulis dalam public participation methods: a framework for evaluation in science (Rowe \& Frewer, 2000); 3) tipologi berdasarkan landasan teori yang pada dasarnya membedakan antara partisipasi normatif dan partisipasi pragmatis. Sebagai contoh, partisipasi yang dibuat oleh Beierle (2002); 4) tipologi berdasarkan tujuan untuk partisipasi yang pernah dilakukan. Seperti dalam Okali dkk. (1994), Michener (1998), Warner (1997), Lynam dkk. (2007), Tippett dkk. (2007).

Karakteristik partisipasi memiliki urut-urutan yang tahap-tahapannya semakin mendekati kepada bentuk ideal partisipasi. Bila dilihat dalam konteks smart city, maka partisipasi yang dibutuhkan adalah mulai dari bentuk yang pasif hingga mendekati kepada bentuk partisipasi yang ideal atau sempurna. Terdapat tiga bentuk karakter partisipasi yang dinilai sesuai dengan konteks smart city, yaitu: partisipasi informatif, partisipasi interaktif dan partisipasi mandiri. 
Pertama, partisipasi informatif, yaitu partisipasi yang hanya melibatkan masyarakat untuk menjawab pertanyaan-pertanyaan, namun tidak berkesempatan untuk terlibat dan mempengaruhi proses keputusan. Kedua, partisipasi interaktif, masyarakat berperan dalam proses analisis untuk perencanaan kegiatan, pembentukan atau penguatan kelembagaan, masyarakat juga berperan untuk mengontrol atas pelaksanaan keputusan-keputusan mereka, sehingga memiliki andil dalam keseluruhan proses kegiatan. Terakhir adalah bentuk partisipasi mandiri (self mobilization), masyarakat mengambil inisiatif sendiri secara bebas (tidak dipengaruhi pihak luar) untuk merubah sistem atau nilai-nilai yang mereka junjung, masyarakat juga memegang kandali atas pemanfaatan sumberdaya yang ada dan atau digunakan (Prety, J., 1995, dalam Syahyuti, 2006).

\section{Partisipasi Masyarakat dalam Konteks Smart City}

Banyak kota di Indonesia khususnya kota-kota besar (seperti Jakarta, Bogor, Bandung, dan Surabaya), mengklaim bahwa kotanya sudah menerapkan konsep smart city (Bappenas, 2015), namun belum dapat dipastikan apakah smart city yang diklaim tersebut telah sesuai dengan visi dan misi smart city yang sebenarnya. Begitu pula halnya dengan warga kota, apakah telah ada kesetaraan dan keadilan dalam mengakses dan menggunakan TIK bagi seluruh lapisan masyarakat, serta apakah masyarakat telah ikut terlibat dan berpartisipasi di dalamnya. Hal ini menjadi tantangan tersendiri dalam melakukan pengembangan dan penerapan konsep smart city.

Keberadaan smart city diharapkan dapat meningkatkan partisipasi masyarakat dalam memanfaatkan aplikasi untuk memberikan masukan maupun kritik dengan mudah kepada pemerintah. Di Indonesia, beberapa program yang dibuat untuk meningkatkan partisipasi masyarakat belum berjalan dengan efektif, hal ini bisa saja disebebkan oleh beberapa hal, namun lebih utamanya disebabkan karena kurangnya sosialisasi kepada masyarakat.

Kota-kota besar seperti Jakarta, Bandung, Tangerang, Malang, dan Surabaya, telah melakukan program "e-Musrenbang" atau musyawarah perencanaan pembangunan secara elektronik. Musrenbang merupakan forum berkumpulnya aktor-aktor yang berkepentingan dalam penyusunan rencana pembangunan nasional maupun rencana pembangunan daerah. Dari forum ini nantinya akan dihasilkan dokumen perencanaan pembangunan, baik rencana pembangunan jangka panjang, jangka menengah, maupun jangka pendek yang dilaksanakan oleh unsur penyelenggara negara dan masyarakat. E-musrenbang diciptakan sebagai sebuah inovasi perencanaan berbasis TIK yang dimanfaatkan untuk menerima partisipasi masyarakat seluas-luasnya dalam menerima berbagai usulan pembangunan.

Dalam tulisannya, Yunas (2017) menyebutkan bahwa Kota Surabaya telah mulai menggunakan e-musrenbang sejak tahun 2010, namun partisipasi yang telah berlangsung dalam proses e-musrenbang masih jauh dari harapan. Kemampuan menangkap aspirasi dan keterwakilan dalam akses e-musrenbang, belum cukup menjamin aspirasi dari masyarakat bawah bisa sampai dan menjadi bagian dari pengambilan keputusan di tahap selanjutnya. Dalam proses penjaringan aspirasi, peluang untuk menyampaikan aspirasi belum sepenuhnya diberikan secara luas kepada masyarakat. Aspirasi atau usulan hanya diberikan kepada beberapa pihak saja dalam hal ini elite di tingkat RW atau Kelurahan. (Yunas, 2017).

Kota Magelang di Provinsi Jawa Tengah juga ikut menciptakan sistem e-musrenbang dengan istilah e-aspiration. e-Aspiration merupakan perwujudan Musrenbang online yang dikembangkan dan digunakan secara non-anggaran oleh pemerintah Kota Magelang sejak tahun 2015. Tujuan menciptakan e-aspiration adalah agar masyarakat dari semua golongan mendapat kemudahan dan kecepatan akses dalam menyampaikan aspirasi, saran, usulan kepada pemerintah. Sedangkan dari sisi pemerintah, diharapkan saluran ini dapat 
menjaring jumlah aspirasi yang lebih besar dari hanya sekedar lewat forum Musrenbang saja. Namun berdasarkan data, e-Aspiration hanya sebuah menu yang ditambahkan pada website Bappeda Kota Magelang, dengan fitur seperti "buku tamu". Data yang ada menunjukkan bahwa sampai dengan Agustus 2017, perbandingan jumlah aspirasi yang masuk, dengan jumlah pengunjung website hanya sekitar $8: 1000$ atau 0,008\% (Diastri, 2017).

Berdasarkan dua kasus di atas, dapat disimpulkan bahwa berdasarkan tujuan diadakannya e-musrenbang, implementasinya yang ada belum sesuai dengan harapan. Partisipasi masyarakat belum bisa disalurkan secara menyeluruh, karena peluang untuk menyampaikan aspirasi tidak diberikan secara luas, usulan hanya diberikan pada pihakpihak tertentu saja, seperti elite di tingkat RW atau kelurahan.

Pada kasus ini, kekuatan konsep smart community perlu diperhitungkan, kelompok yang memiliki kapasitas dalam memberikan aspirasi, diharapkan dapat menjadi wakil masyarakat dalam mewakili dan merepresentasikan kelompoknya, sehingga memiliki kemampuan dalam menyampaikan aspirasi dengan suasana yang mendukung. Dengan memperkuat konsep smart community, maka dapat dipastikan suara masyarakat dari tingkat terbawah dapat dihadirkan dan nantinya bisa mempengaruhi kebijakan-kebijakan pada proses pembangunan kota.

Selain e-musrenbang, kota-kota lain di Indonesia juga menciptakan beragam sistem lainnya untuk menciptakan kualitas layanan publik yang lebih baik melalui penjaringan aspirasi dan partisipasi masyarakat kota secara luas. Kota Surabaya menciptakan sistem lain yang dibagi menjadi dua kelompok, yaitu: 1) bagian tata kelola keuangan seperti ebudgeting, e-procurement, e-delivery, e-controlling, dan e-performance; dan 2) bagian layanan publik seperti e-perizinan, e-health, dan e-complaint yang dibuat menjadi satu bernama e-sapawarga (Alamsyah, Susanto, \& Chou, 2016). Kota Bandung sebagai salah satu kota yang sangat intensif melakukan pengembangan TIK untuk implementasi smart city, menerapkan sistem elektronik dalam menjaring aspirasi masyarakat melalui pengembangan: Layanan lapor.ukp.go.id, sebagai media untuk pelaporan masyarakat terhadap kinerja pemerintahan; Layanan Bandung government official twitter sebagai media komunikasi terbuka antara pemerintah Kota Bandung (termasuk walikota) dengan warga Bandung; Layanan portal tanya jawab Bandung, sebagai media komunikasi dan diskusi tentang kota Bandung; dan Layanan Bandung open apps, sebagai penyedia aplikasi penunjang layanan, komunikasi dan transaksi untuk akses melalui smart phone (Elysia, Wihadanto, \& Sumartono, 2017).

Program-program yang diluncurkan oleh pemerintah kota tersebut diciptakan untuk menjaring aspirasi warga kota, namun belum dapat dipastikan apakah harapan tersebut dapat terwujud dan dapat menyentuh pada seluruh lapisan masyarakat, khususnya kelompok masyarakat paling bawah yang umumnya adalah warga miskin yang paling berhak untuk menerima layanan dan berpartisipasi secara utuh.

\section{Karakter Smart City Pendukung Partisipatif}

Beberapa model konseptual smart city yang ada saat ini telah mulai mengarah kepada pendekatan yang lebih fokus kepada manusia, masyarakat, modal sosial, inklusi, dan lain-lain. Secara lebih spesifik, karakter konsep smart city yang mendukung kepada perlunya peningkatan partisipasi masyarakat juga telah terlihat. Model komponen dasar smart city oleh (Nam \& Pardo, 2011) menyebutkan bahwa, terdapat tiga komponen utama yang memiliki hubungan organik yaitu: faktor teknologi, faktor manusia, dan faktor institusi. Ketiganya saling terhubung dan terikat satu sama lainnya. Dalam konteks konsep smart city menuju partisipatif, faktor institusi merupakan salah satu faktor utama dalam hal mendukung dan menguatkan partisipatif, namun faktor ini tentu saja tidak dapat berjalan 
sendiri, sehingga juga dibutuhkan dukungan dua faktor lainnya yaitu faktor teknologi dan manusia.

Unsur-unsur yang mendukung faktor institusi adalah adanya pemerintahan, kebijakan, dan peraturan, yang selanjutnya berlanjut kepada konsep yang mendukung munculnya partisipasi yaitu smart community. Smart community mulai muncul dari lingkungan kecil hingga masyarakat umum yang memiliki kepentingan bersama dan kepentingan untuk berbagi, anggotanya terdiri dari kelompok-kelompok organisasi dan institusi pemerintahan yang bekerja dengan kerjasama untuk menggunakan TIK dan untuk mengubah keadaan mereka dengan cara yang signifikan (Nam \& Pardo, 2011).

Berdasarkan Smart Community International Network (SCIN)'s (2003) definisi smart community adalah komunitas dengan visi masa depan dan menggunakan TIK dengan cara baru dan inovatif untuk memberdayakan penduduk, institusi, dan wilayah secara keseluruhan. Smart community memanfaatkan peluang yang dapat disediakan oleh aplikasi baru seperti pemberian layanan kesehatan yang lebih baik, pendidikan dan pelatihan yang lebih baik, serta adanya peluang bisnis baru (Lindskog, 2004). Dalam usaha meningkatkan partisipasi masyarakat, smart community salah satunya dilakukan dengan e-demokrasi melalui bentuk-bentuk partisipasi dan pemberdayaan masyarakat.

Teknologi informasi komunikasi (TIK) berfungsi sebagai alat, tidak cukup hanya dengan mengandalkan TIK, maka akan tercipta sebuah smart community. TIK dan aplikasinya digunakan untuk memfasilitasi keterlibatan semua pihak, namun hal yang lebih penting dalam membentuk smart community adalah memberikan kesempatan untuk meningkatkan partisipasi masyarakat, sehingga dapat mempengaruhi pengambilan keputusan secara lokal melalui keterlibatan, kolaborasi, dan kerja sama antara lembaga publik, organisasi, sekolah, dan kelompok-kelompok masyarakat (Coe, dkk., 2001). Oleh sebab itu fenomena smart community merupakan fenomena yang bersifat global karena ada di seluruh dunia dan juga terdapat dalam skala lokal yang didasarkan pada inisiatif lokal (Lindskog, 2004).

Model smart city lainnya yang mendukung terciptanya partisipasi masyarakat adalah Europe smart city model yang dikemukakan oleh Giffinger \& Gudrun (2010). Mereka menyebutkan, sebuah smart city merupakan kota yang memiliki performa baik dalam enam karakterisitik (smart people, smart living, smart economy, smart environment, smart governance, dan smart mobility), dibangun dengan kombinasi yang smart, antara: dukungan-dukungan, keputusan-keputusan (peraturan), serta kebebasan dan kesadaran masyarakat dlm menentukan aktivitasnya.. Dari definisi tersebut, dapat dilihat bahwa peran masyarakat sangat penting dalam membangun smart city. Enam karakteristik dalam model konseptual ini, yaitu: smart economy, smart people, smart environment, smart living, smart mobility dan smart governance. Dalam konteks partisipasi masyarakat, maka karakter smart governance dan smart people sangat berhubungan dan penting untuk dikembangkan. Masing-masing karakter memiliki faktor-faktor yang relevan dan indikator.

Menurut Giffinger \& Gudrun (2010), karakteristik smart people tidak hanya selalu berkaitan dengan tingkat pendidikan masyarakat, tetapi juga dilihat dari kualitas interaksi sosial masyarakat, kualitas kehidupan publik, dan memiliki keterbukaan terhadap dunia luar. Dalam Europe smart city model, smart people sangat berkaitan dengan tingkat modal sosial dan modal manusia (social and human capita), serta memiliki tujuh faktor utama sebagai pembentuknya, yaitu: kualifikasi dan tingkat pendidikan, pembelajaran seumur hidup, kemajemukan sosial dan etnis, partisipasi dalam kehidupan publik, fleksibilitas, kreativitas, dan pemikiran yang terbuka. Dalam konteks partisipasi, smart people memiliki indikator seperti tingkat pemilih yang ikut berpartisipasi pada pemilihan kepala daerah, dan tingkat partisipasi masyarakat yang mau ikut berpartisipasi dalam pekerjaan atau proyek tertentu secara sukarela. 
Selain smart people, smart governance merupakan cerminan dari: aspek partisipasi politik, layanan yang diberikan bagi warga masyarakat, serta adanya fungsi administrasi. Good governance merupakan salah satu cerminan dari penciptaan smart governance. Smart governance yang sangat erat kaitannya dengan partisipasi masyarakat, memiliki enam faktor yang membentuknya, yaitu: partisipasi masyarakat dalam pengambilan keputusan, layanan publik dan sosial, pemerintahan yang transparan, serta strategi dan perspektif politik (Giffinger \& Gudrun, 2010). Smart governance juga sangat identik dengan sistem penggunaan saluran komunikasi baru yang terbuka bagi masyarakat, seperti $e$ government dan e-demokrasi.

E-government atau kata lainnya pemerintahan digital, merupakan kegiatan yang diselenggarakan oleh pemerintah dengan dukungan TIK dan bertujuan untuk: mendorong pemerintahan yang responsif terhadap kebutuhan dan aspirasi masyarakat, mendorong sisi pemanfaatan dari keterbukaan informasi, dan mendorong tingkat partisipasi publik didalam sistem penyelenggaraan pemerintahan (Hasibuan \& Santoso, 2005). Giffinger dan Gudrun (2010) juga menentukan indikator dalam menentukan tingkat keberhasilan partisipasi suatu kota melalui smart governance, yaitu: melihat tingkat perwakilan partisipasi kota per jumlah penduduk, bagaimana aktivitas politik masyarakat, pentingnya politik bagi masyarakat dalam menyampaikan aspirasi, tingkat perwakilan perempuan, pengeluaran kota per jumlah penduduk, tingkat kepuasan terhadap kualitas sekolah, tingkat kepuasan terhadap transparansi birokrasi, dan tingkat kepuasan terhadap pemberantasan korupsi.

Dari pembahasan di atas, maka dapat diketahui terdapat tiga faktor utama yang harus dimiliki dan diperhatikan dalam upaya mewujudkan partisipasi masyarakat yang ideal, yaitu penguatan dalam konsep smart community, smart governance, dan smart people. Keterkaitan ketiganya dapat digambarkan sebagai suatu konsep baru dalam menguatkan tingkat partisipasi masyarakat untuk mewujudkan konsep smart city yang ideal, sesuai dengan proses evolusi perjalanan konsep smart city.

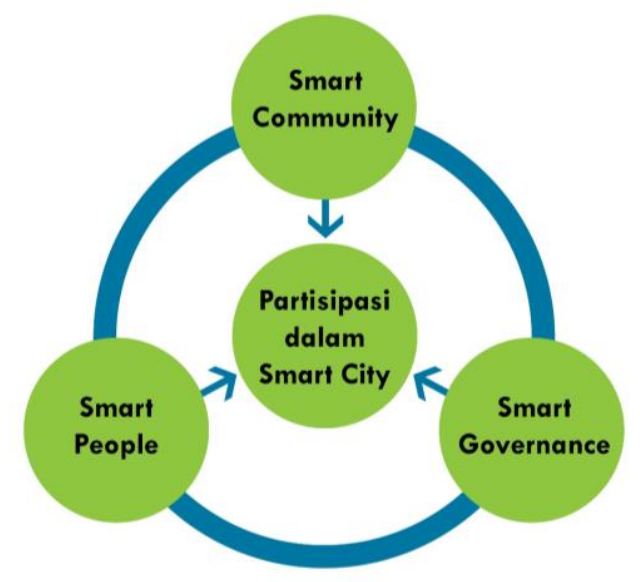

Gambar 1. Kerangka Konseptual Pembentuk Partisipasi dalam Konsep Smart City

Dari kerangka konseptual ini (gambar 1) dapat dilihat bahwa, smart people, smart community, dan smart governance saling terhubung dan terkait satu dengan lainnya, serta menjadi satu kesatuan dalam upaya mewujudkan smart city yang partisipatif. Dari ketiga komponen tersebut, bila dilihat dari skala dan lingkup terkecil, maka penguatan dimulai dari komponen smart people, selanjutnya berkembang menuju komponen smart community, dan yang terakhir dalam skala yang lebih besar memperkuat komponen smart governance. Smart people akan fokus dan berorientasi pada modal sosial dan modal 
manusia dalam usaha meningkatkan partisipasi warga, selanjutnya smart community menjadi kelompok-kelompok yang berusaha lebih baik memperjuangkan hak dan kewajibannya dalam partisipasi sebagai warga melalui teknologi informasi dan komunikasi, serta smart governance yang mempersiapkan fasilitas bagi warga untuk menyampaikan aspirasinya, mendengar kebutuhan warganya, dan memberikan layanan terbaik bagi warga kotanya.

\section{KESIMPULAN}

Berdasarkan pembahasan di atas, dapat disimpulkan bahwa partisipasi masyarakat dalam konteks smart city merupakan kontribusi secara sukarela dari masyarakat kepada pemerintah baik dalam proses pembangunan, peningkatan pelayanan, kesiapsiagaan bencana, maupun administratif. Partisipasi tersebut dapat disampaikan melalui fasilitas yang disediakan pemerintah, baik melalui sistem TIK maupun tidak. Kemudahan TIK bukanlah satu-satunya cara yang didorong untuk dapat menyampaikan aspirasi dan kontribusi, pemerintah harus tetap menarik masyarakat melalui beragam cara, baik secara konvensional maupun tradisional. Efektifitas keterlibatan masyarakat tergantung pada kesediaan mereka untuk ikut berpartisipasi, dan masyarakat juga harus percaya bahwa dengan adanya partisipasi mereka maka nantinya akan memberi dampak positif bagi komunitasnya.

Berdasarkan tipologi partisipasi, model pemerintahan partisipatif berbasis konsep smart city lebih cenderung berada pada model tipologi yang mengarah kepada: (1) tipologi berdasarkan sifat dasar partisipasi, yaitu sesuai dengan arah arus komunikasi, seperti dalam public participation methods: a framework for evaluation in science (Rowe \& Frewer, 2000), dan (2) tipologi partisipasi berdasarkan landasan teori yang pada dasarnya membedakan antara partisipasi normatif dan partisipasi pragmatis. Sebagai contoh, partisipasi yang dibuat oleh Beierle (2002). Pada karakteristiknya, partisipasi berbasis konsep smart city berada dalam karakteristik partisipasi yang pasif, partisipasi informatif, dan partisipasi interaktif, yang memberikan peran dalam proses analisis perencanaan kegiatan.

Tiga komponen penting dalam penguatan partisipasi dalam konteks smart city, yaitu smart people, smart community, dan smart governance. Smart people atau warga kota yang cerdas, merupakan objek penting dalam kegiatan partisipasi, warga harus selalu merasa dibutuhkan, meskipun kegiatan partisipasi adalah kegiatan yang bebas dan tidak terikat. Namun peran dan kualitas partisipasi yang diberikan akan sangat berpengaruh terhadap hasil pembangunan nantinya dan harus dapat diterima dengan baik oleh masyarakat. Selanjutnya, dengan memaksimalkan komponen smart community, maka diharapkan tercipta partisipasi yang bersifat efisien, inklusif, dan terbuka, baik bagi kelompok-kelompok terbawah hingga ke atas. Nilai-nilai demokrasi dalam partisipasi harus tetap diadopsi dan diadaptasi berdasarkan nilai-nilai kontekstual yang ada. Terakhir, yaitu smart governance, komponen ini diharapkan dapat menjadi fasilitator utama dalam mewujudkan pemerintahan yang partisipatif, terbuka, tata kelola masyarakat yang cerdas, tata kelola pemerintahan yang saling terkoneksi dan terintegrasi, serta adanya peningkatan akses terhadap layanan yang ada (Scholl \& Scholl, 2014; \& Abdoullaev, 2011).

Melalui penerapan ketiga komponen tersebut di atas, maka model pemerintahan partisipatif diharapkan dapat lebih baik penerapan, pelaksanaan, dan pengembangannya, jika dijalankan melalui konsep smart city. Perpaduan antara smart people, smart community, dan smart governance dari skala yang paling bawah hingga skala paling atas, diharapkan dapat meningkatkan keefektifan dan efisiensi peran pemerintah dalam membentuk dan mewujudkan pemerintahan yang partisipatif, sehingga nantinya dapat 
meningkatkan pelayanan pemerintah kepada publik, mendengar dan mengerti kebutuhan dan aspirasi publik, serta meningkatkan respon pemerintah kepada publik.

\section{DAFTAR PUSTAKA}

Abdoullaev, A. (2011). A Smart World: A Development Model for Intelligent Cities Cities. In The 11th IEEE International Conference on Computer and Information Technology (CIT-2011) Proceeding. Cyprus: IEEE.

Alamsyah, N., Susanto, T. D., \& Chou, T. C. (2016). A comparison study of smart city in Taipei and Surabaya. In 2016 International Conference on ICT For Smart Society (ICISS) (pp. 111-118). https://doi.org/10.1109/ICTSS.2016.7792859

Angelidou, M. (2014). Smart city policies: A spatial approach. Cities, 41, S3-S11. https://doi.org/10.1016/j.cities.2014.06.007

Arnstein, S. R. (1969). A Ladder Of Citizen Participation. Journal of the American Institute of Planners, 35(4), 216-224. https://doi.org/10.1080/01944366908977225

Beierle, T. C. (2010). Democracy in Practice: Public Participation in Environmental Decisions. https://doi.org/10.4324/9781936331017

Bosch, H. van den. (2017, July 4). Smart Cities 1.0, 2.0, 3.0. What's next? Retrieved February 17, 2018, from http://smartcityhub.com/collaborative-city/smart-cities-1-0-2-0-3-0-whats-next/

Caragliu, A., Del Bo, C., \& Nijkamp, P. (2011). Smart Cities in Europe. Journal of Urban Technology, 18(2), 6582. https://doi.org/10.1080/10630732.2011.601117

Chourabi, H., Nam, T., Walker, S., Gil-Garcia, J. R., Mellouli, S., Nahon, K., ... Scholl, H. J. (2012, January). Understanding Smart Cities: An Integrative Framework. 2289-2297. https://doi.org/10.1109/HICSS.2012.615

Christine Okali, James Sumberg, \& John Farrington. (1994). Farmer Participatory Research (First Edition). Practical Action.

Cocchia, A. (2014a). Smart and Digital City: A Systematic Literature Review. In R. P. Dameri \& C. RosenthalSabroux (Eds.), Smart city (pp. 13-43). Cham: Springer International Publishing. Retrieved from http://link.springer.com/10.1007/978-3-319-06160-3_2

Cocchia, A. (2014b). Smart and Digital City: A Systematic Literature Review. In R. P. Dameri \& C. RosenthalSabroux (Eds.), Smart city (pp. 13-43). Cham: Springer International Publishing. Retrieved from http://link.springer.com/10.1007/978-3-319-06160-3_2

Coe, A., Paquet, G., \& Roy, J. (2001). E-Governance and Smart Communities: A Social Learning Challenge. Social Science Computer Review, 19(1), 80-93. https://doi.org/10.1177/089443930101900107

Colding, J., \& Barthel, S. (2017). An urban ecology critique on the "Smart city" model - ScienceDirect. Journal of Cleaner Production, 164(5 October 2017), 95-101. https://doi.org/10.1016/j.jclepro.2017.06.191

Dameri, R. P., \& Rosenthal-Sabroux, C. (Eds.). (2014). Smart city and Value Creation. In Smart city (pp. 1-12). Cham: Springer International Publishing. Retrieved from http://link.springer.com/10.1007/978-3-31906160-3_2

Davidson, S. (1998). Spinning the wheel of empowerment. Planning, 3.

Diastri, A. I. (2017). Penggunaan E-Government dan Media Sosial oleh Pemerintah Kota Magelang dalam Proses Pembangunan Partisipatif (Transisi Kota Magelang menjadi Kota Cerdas). Universitas Gadjah Mada. $\quad$ Retrieved from http://etd.repository.ugm.ac.id/index.php?act=view\&buku_id=131739\&mod=penelitian_detail\&sub=P enelitianDetail\&typ=html

Elysia, V., Wihadanto, A., \& Sumartono. (2017). Implementasi e-Government untuk Mendorong Pelayanan Publik Yang Terintegrasi di Indonesia. In Optimalisasi Peran Sains dan Teknologi untuk Mewujudkan Smart city (pp. 353-380). Tangerang Selatan: Universitas Terbuka.

European Commission. (2012). Communication from the commission. Smart cities and communities European innovation partnership. Brussels.

Fung, A. (2006). Varieties of Participation in Complex Governance. Public Administration Review, 66, 66-75. https://doi.org/10.1111/j.1540-6210.2006.00667.x

Francis, C., \& Baldesari. (2006). Systematic Reviews of Qualitative Literature. Oxford: UK Cochrane Centre.

Giffinger, R., \& Gudrun, H. (2010). Smart cities ranking: an effective instrument for the positioning of the cities? ACE: Architecture, City and Environment, a(12). Retrieved from http://www.raco.cat/index.php/ACE/article/view/188052 
Hasibuan, Z. A., \& Santoso, H. B. (2005). Standardisasi aplikasi e-government untuk instansi pemerintah. Prosiding Konferensi Nasional Teknologi Informasi dan Komunikasi Indonesia - ITB, Bandung.

Hollands, R. G. (2008). Will the real smart city please stand up?: Intelligent, progressive or entrepreneurial? City, 12(3), 303-320. https://doi.org/10.1080/13604810802479126

IEEE (the Institute of Electrical and Electronics Engineers). (2014). IEEE Smart Cities. Retrieved from http://smartcities.ieee.org/about.html

Jucevičius, R., Patašienè, I., \& Patašius, M. (2014). Digital Dimension of Smart city. Critical Analysis. Procedia Social and Behavioral Sciences, 156, 146-150. https://doi.org/10.1016/j.sbspro.2014.11.137

Krivý, M. (2016). Towards a critique of cybernetic urbanism: The smart city and the society of control. Planning Theory, 1473095216645631. https://doi.org/10.1177/1473095216645631

Lindskog, H. (2004). Smart communities initiatives. In Proceedings of the 3rd ISOneWorld Conference (Vol. 16).

Lynam, T., de Jong, W., Sheil, D., Kusumanto, T., \& Evans, K. (2007). A Review of Tools for Incorporating Community Knowledge, Preferences, and Values into Decision Making in Natural Resources Management. Ecology and Society, 12(1). https://doi.org/10.5751/ES-01987-120105

Marsal-Llacuna, M.-L., Colomer-Llinàs, J., \& Meléndez-Frigola, J. (2015). Lessons in urban monitoring taken from sustainable and livable cities to better address the Smart Cities initiative. Technological Forecasting and Social Change, 90, 611-622. https://doi.org/10.1016/j.techfore.2014.01.012

Meijer, A., \& Bolívar, M. P. R. (2016). Governing the smart city: a review of the literature on smart urban governance. International Review of Administrative Sciences, 82(2), 392-408. https://doi.org/10.1177/0020852314564308

Michener, V. J. (1998). The participatory approach: Contradiction and co-option in Burkina Faso. World Development, 26(12), 2105-2118.

Nam, T., \& Pardo, T. A. (2011). Conceptualizing smart city with dimensions of technology, people, and institutions (p. 282). ACM Press. https://doi.org/10.1145/2037556.2037602

Oberti, I., \& Pavesi, A. S. (2013). The triumph of the smart city. TECHNE - Journal of Technology for Architecture and Environment, O(5), 117-122. https://doi.org/10.13128/Techne-12810

Papa, R., Galderisi, A., Vigo Majello, M. C., \& Saretta, E. (2015). Smart and Resilient Cities. A Systemic Approach for Developing Cross-sectoral Strategies in the Face of Climate Change. TeMA - Journal of Land Use, Mobility and Environment, 8(1):19-49. https://doi.org/10.6092/1970-9870/2883

Parwoto. (1997). Pembangunan Partisipatif. In Lokakarya Penerapan Strategy Pemberdayaan Masyarakat dalam Pembangunan Perumahan dan Permukiman. Jakarta: BKP4N.

Perry, A., \& Hammond, N. (2002). Systematic Review: The Experience of a PhD Student. 2 (1).

Peters, B. G. (1996). The future of governing: four emerging models. University Press of Kansas.

Reed, M. S. (2008). Stakeholder participation for environmental management: A literature review. Biological Conservation, 141(10), 2417-2431. https://doi.org/10.1016/j.biocon.2008.07.014

Rowe, G., \& Frewer, L. J. (2000). Public Participation Methods: A Framework for Evaluation. Science, Technology, \& Human Values, 25(1), 3-29. https://doi.org/10.1177/016224390002500101

Rudolf, G., Fertner, C., Kramar, H., Kalasek, R., Pichler-Milanovic, N., \& Meijers, E. (2007). Smart cities-ranking of european medium-sized cities. Rapport Technique, Vienna Centre of Regional Science.

Salakory, H. L. (1997). Aspirasi dan Partisipasi Rakyat dalam Pembangunan Politik: Filosofi dan Sejarahnya di Indonesia. Bina darma.

Scholl, H. J., \& Scholl, M. (2014). Smart Governance: A Roadmap for Research and Practice. In iConference 2014 Proceedings. Berlin: iSchools. https://doi.org/10.9776/14060

Siagian, S. P. 1933-(Painan). (2000). Administrasi pembangunan: konsep, dimensi, dan strategi.

$\mathrm{Su}, \quad$ K., Li, J., \& Fu, H. (2011). Smart city and the applications (pp. 1028-1031). IEEE. https://doi.org/10.1109/ICECC.2011.6066743

Syahyuti, S. (2006). Tiga Puluh Konsep Penting Pembangunan Pedesaan dan Pertanian. Jakarta: PT. Bina Rena Pariwara.

Townsend, A. M. (2013). Smart Cities: Big Data, Civic Hackers, and the Quest for a New Utopia (1 edition). New York: W. W. Norton \& Company.

Wall, R. S., \& Stavropoulos, S. (2016). Smart cities within world city networks. Applied Economics Letters, 23(12), 875-879. https://doi.org/10.1080/13504851.2015.1117038 
Warner, M. (1997). 'Consensus' participation: an example for protected areas planning. Public Administration and Development, 174), 413-432. https://doi.org/10.1002/(SICI)1099-162X(199710)17:4<413::AIDPAD952>3.0.CO;2-P

Yunas, N. S. (2017). Efektivitas E-Musrenbang di Kota Surabaya dalam Sistem Perencanaan Pembangunan Berparadigma Masyarakat. Otoritas: Jurnal Ilmu Pemerintahan, 71), 19-27. https://doi.org/10.26618/ojip.v7i1.387 